\title{
The N363S polymorphism in the glucocorticoid receptor gene: effects on visceral fat assessed by abdominal computed tomography
}

\author{
Polimorfismo N363S do gene do receptor de glucocorticoide: efeito \\ sobre a adiposidade visceral medida pela tomografia computadorizada
}

Cintia Cercato', Alfredo Halpern', Eliana S. T. Frazzatto², Izabel Cristina Guazzelli², Sandra Mara Ferreira Villares ${ }^{3}$

${ }^{1}$ Grupo de Obesidade e

Síndrome Metabólica, Serviço de Endocrinologia e Metabologia,

Hospital das Clínicas da Faculdade de Medicina da Universidade de São Paulo (HC-FMUSP), São Paulo, SP, Brasil

${ }^{2}$ Laboratório de Nutrição Humana e Doenças Metabólicas (LIM-25). Faculdade de Medicina da Universidade de São Paulo (FMUSP), São Paulo, SP, Brasil ${ }^{3}$ Grupo de Obesidade e Síndrome Metabólica, Serviço de Endocrinologia e Metabologia, Hospital das Clínicas da Faculdade de Medicina da Universidade de São Paulo (HC-FMUSP), São Paulo, SP, Brasil; Laboratório de Nutrição Humana e Doenças Metabólicas (LIM-25), FMUSP, São Paulo, SP, Brasil

Correspondence to: Cíntia Cercato

Rua Dr. Enéas de Carvalho Aguiar, $1555^{\circ}$ andar, bloco $4 B$, sala11-A 05403-000 - São Paulo, SP, Brasil ccercato@netpoint.com.br

Received in Nov/26/2008 Accepted in Feb/16/2009

\begin{abstract}
Objective: To verify whether N363S polymorphism of the glucocorticoid receptor-gene can be associated to visceral fat by CT scan in obese individuals, and the impact of this variant on metabolic profile. Methods: The N363S variant was screened in 295 Brazilians, 195 were obese and 100 presented normal weight. Based on genotype, obese N363S SNP carriers were paired with obese wild-type subjects. This group was submitted to a CT scan and metabolic profile assessment. Results: Ten subjects were found to be heterozygous for the variant (A/G genotype frequency $3.4 \%), 8(4.1 \%)$ obese and $2(2.0 \%)$ non-obese. No differences were reported for visceral adiposity area (145.8 \pm 49.9 vs. $\left.147.7 \pm 48.8 \mathrm{~cm}^{2} ; \mathrm{p}=0.92\right)$ based on CT scan results but N363S SNP carriers showed a proneness to unfavorable metabolic changes. Conclusion: The N363S polymorphism prevalence is low in the Brazilian population, although its presence may contribute to the worsening of individuals' metabolic profiles. Arq Bras Endocrinol Metab. 2009;53(2):288-292.
\end{abstract}

Keywords

Glucocorticoid; polymorphism; obesity; metabolic syndrome

\section{RESUMO}

Objetivo: Verificar se a presença do polimorfismo N363S do gene do receptor de glucocorticoide estaria associada, em indivíduos obesos, à presença de adiposidade visceral pela tomografia computadorizada, e sobre o impacto desta variante genética no perfil metabólico. Métodos: A variante N363S do receptor do glicocorticoide foi verificada em um grupo de 295 indivíduos brasileiros, sendo 295 obesos e 100 com peso normal. Com base na genotipagem, os indivíduos obesos carreadores do polimorfismo N363S foram pareados com obesos normais. 0 grupo com polimorfismo foi submetido a exames de tomografia computadorizada abdominal e laboratoriais para a caracterização de seu perfil metabólico. Resultados: Dez indivíduos eram heterozigotos para a variante AG $(3,4 \%)$, sendo oito obesos $(4,1 \%)$ e dois não-obesos $(2 \%)$. Não foram encontradas diferenças na quantidade de adiposidade visceral $(145,8 \pm 49,9$ versus $147,7 \pm 48,8 \mathrm{~cm}^{2} ; p=0,92$ ) baseados no TC de abdômen. No entanto, os indivíduos carreadores do N363S SNP (single nucleotide polymorphism) apresentaram tendência a perfil metabólico desfavorável. Conclusão: O polimorfismo N363S do gene do receptor de glucocorticoide teve prevalência baixa na população estudada. A sua presença pode contribuir para a deterioração do perfil metabólico desses indivíduos. Arq Bras Endocrinol Metab. 2009;53(2):288-292.

Descritores

Glicocorticoide; polimorfismo; obesidade; síndrome metabólica 


\section{INTRODUCTION}

Come obesity phenotypes - mainly those with abdom$\checkmark$ inal adiposity - report clear characteristics of hypercortisolism despite keeping serum cortisol levels within normal ranges $(1,2)$. Most glucocorticoid action is carried out through cortisol binding with an intracellular protein - the glucocorticoid receptor (GR) (3). The GR is part of the Type 1 subclass of nuclear receptors (4). The gene that codifies the GR (NR3C1) is located on the long arm of chromosome 5 , in the $5 \mathrm{q} 31$-q32 region. GR expression level and receptor hormone binding affinity are the main determinants of tissue sensitivity (3). Recent data have suggested that GR phosphorylation may determine specificity to target receptors, interaction with co-factors, cellular localization, and receptor stability (5). In 1997, Koper and cols. (6) described a GR polymorphism located at nucleotide position 1220 (AAT to AGT), resulting in a change of asparagine into serine at codon 363 (N363S SNP) in the GR transactivation domain. The presence of a new serine site in the transcription-activating amino-terminal region could lead to phosphorylation increase, as well as to higher receptor activity. Recently, examination of this polymorphism by microarray analysis showed that there are significant differences between wild-type GR and the N363S SNP in their ability to regulate gene expression selectively (7). Several of these genes may define the link between the N363S SNP and the human disease. In a Dutch study, a group of 216 elderly individuals were examined for the N363S polymorphism gene, and 13 heterozygotes ( $6 \%$ of the group) were identified. Interestingly, these carriers exhibited an increased sensitivity to exogenously administered glucocorticoids as well as an increased insulin response and increased body mass index (BMI) (8). Other studies also associated the presence of the N363S variant with body weight increase by analyzing BMI in a population of Australians of British origin (9), obese individuals in Italy (10), and diabetics in France (11). The same association could not be found in Danish individuals (12), or Swedish males (13).

Hypercortisolism patients present visceral obesity as a marked feature, although BMI in the same individuals is not always higher. Higher sensitivity to glucocorticoids may also be a predominant influence on abdominal adiposity distribution, as demonstrated by Dobson and cols., 2001 (14), who showed the association between $\mathrm{N} 363 \mathrm{~S}$ polymorphism and waist-hip ratio in men. However, that has not been proven by other studies, which also used only anthropometric measures for the assessment of body fat distribution $(10,13)$. Nowadays, it has also been demonstrated that the best method for the assessment of visceral adiposity is abdominal computed tomography (CT) scan (15) - not used in any study with carriers of this kind of polymorphism. The purpose of this study was to verify whether N363S polymorphism could be associated to visceral adiposity when assessed by abdominal CT scan on phenotypes associated with a metabolic syndrome such as insulin resistance, systemic arterial hypertension, increased levels of plasminogen 1 activator inhibitor (PAI-1).

\section{METHODS}

\section{Study Population}

This study was approved by the Ethics Committee and all participants signed informed consent form. The assessment included 295 individuals, of whom 195 are obese, and 100 are of normal weight according to BMI values. In the obese individuals $(\mathrm{n}=195)$ group, 168 were females $(86.1 \%)$ and 27 were males (13.9\%). All participants were healthy individuals, in the age range of 18-55 years, and $\mathrm{BMI} \geq 30 \mathrm{~kg} / \mathrm{m}^{2}$ and $<40 \mathrm{~kg} / \mathrm{m}^{2}$, with central distribution of adiposity (abdominal circumference $\geq 80 \mathrm{~cm}$ and waist-hip ratio $>0.8$ in women, and abdominal circumference $\geq 94 \mathrm{~cm}$ and waist-hip ratio $>0.95$ in men). Individuals of Asian ancestry or those reporting serious systemic conditions or persons with a history of systemic use of glucocorticoid in the previous 5 years were excluded.

\section{Genetic analysis}

Genomic DNA was extracted from peripheral blood samples by standard procedures. The N363S SNP was examined by a restriction fragment length polymorphism (RFLP) technique following polymerase chain reaction (PCR) amplification with primers 5'-TGCCATTTCTGTTCATGGTG-3' (forward) and 5'-CTGAACTTCCCTGGTCGAAC-3' (reverse). PCR conditions were initial denaturation at $94{ }^{\circ} \mathrm{C}$ for $4 \mathrm{~min}$, and 35 cycles at $94{ }^{\circ} \mathrm{C}$ for denaturation, $58{ }^{\circ} \mathrm{C}$ for annealing and $72{ }^{\circ} \mathrm{C}$ for extension, each step lasting $\mathrm{l}$ min, with a final extension of 7 min at $72{ }^{\circ} \mathrm{C}$. Amplification yielded a 210-bp fragment that contained two Tsp509I restriction sites $(117+74+19$ bp) for the A-allele (N363) and only one (117+93 bp) for the G-allele (363S). Following enzymatic digestion, PCR products were resolved on $3 \%$ agarose gel electrophoresis and visualized by ethidium bromide staining. 


\section{Study protocol}

All individuals were submitted to genetic analysis for the identification of N363S SNP. Based on genotype identification, N363S SNP obese carriers were carefully paired with non-carriers, at a 1:5 ratio following gender, race, age group, body weight, height and BMI, and were submitted to regional body fat measurements with CT scans, in addition to analysis of metabolic parameters such as glycemia, insulin, HOMA-IR, total cholesterol and fractions, triglycerides, APOB, blood pressure and PAI-1.

In order to determine intra-abdominal and abdominal subcutaneous adiposity, a CT scan was carried out following the technique standardized by Sjöstrom and Kvist in 1988 (16). Plasma glucose level was determined by Roche Cobas Integra Model, through colorimetric enzyme assay, using hexokinase. Serum insulin concentration was determined by radio immunoassay by Linco Reseach, Inc. (USA) HI-14K. Analysis of insulin resistance was carried out through the homeostasis model assessment (HOMA) using the following formula: insulin resistance $(\mathrm{IR})=$ insulin $(\mu \mathrm{U} / \mathrm{mL}) \times$ glucose $(\mathrm{mmol} / \mathrm{L}) / 22.5(17)$. Total cholesterol (TC), HDL-C and plasma triglyceride (TG) levels were determined by COBAS MIRA automated system (F. Hoffmann-La Roche, Basel, Switzerland), by Roche's commercial enzyme kits (Mannheim, Germany). PAI-1 plasma concentration was determined by IMUNOBIND ${ }^{\circledR}$ Plasma PAI-1 ELISA using the CPT 85400 kit by American Diagnostica Inc. (USA).

\section{Statistical analysis}

Results were expressed as mean \pm standard deviation (SD) for quantitative variables. Absolute and relative frequencies were calculated for qualitative variables. Student's $t$-test was used for equality hypothesis between averages in both groups. Fisher's exact test was used for group homogeneity testing compared to ratios. The significance level used for testing was $5 \%$.

\section{RESULTS}

A group of 295 individuals was examined for the N363S polymorphism, and 10 heterozygotes were identified (A/G genotype frequency was 3.4\%; G-allele frequency was $1.7 \%$ ). The obese individuals presented a double frequency of N363S SNP as compared to normal body weight individuals (Table 1). Waist, waist-hip, abdominal visceral adiposity (VA) and abdominal subcutaneous adiposity (SA), as well as the ratio VA/SA were compared be- tween N363S SNP carriers and their paired controls, and no differences were found between the groups (Table 2).

Metabolic parameters between N363S SNP carriers and paired non-carriers can be found in Table 3. In patients with N363S SNP a tendency to higher insulin resistance by HOMA-IR assessment, higher levels of systolic blood pressure (SBP) and lower HDL-cholesterol levels was noted.

\begin{tabular}{lcc}
\hline \multicolumn{3}{l}{ Table 1. Genotype frequencies according to BMI levels } \\
\hline BMI & $\begin{array}{c}\text { N363/N363 } \\
\text { (genotype AA) }\end{array}$ & $\begin{array}{c}\text { N363/363S } \\
\text { (genotype AG) }\end{array}$ \\
\hline$<25 \mathrm{~kg} / \mathrm{m}^{2}$ & $98(98.0 \%)$ & $2(2.0 \%)$ \\
$\geq 30 \mathrm{~kg} / \mathrm{m}^{2}$ & $187(95.9 \%)$ & $8(4.1 \%)$ \\
Total population & $285(96.6 \%)$ & $10(3.4 \%)$ \\
\hline
\end{tabular}

\begin{tabular}{lccc}
\hline \multicolumn{4}{c}{ Table 2. Demographic and anthropometric characteristics according to genotype } \\
\hline & $\begin{array}{c}\text { N363/363S } \\
\text { (genotype } \\
\text { AG) }\end{array}$ & $\begin{array}{c}\text { N363/N363 } \\
\text { (genotype } \\
\text { AA) }\end{array}$ & P \\
\hline Subjects & 8 & 40 & \\
Females & $100 \%$ & $100 \%$ & \\
Age (years) & $35.0 \pm 7.9$ & $33.8 \pm 6.3$ & 0.64 \\
Body weight (kg) & $88.6 \pm 7.0$ & $88.9 \pm 7.2$ & 0.93 \\
Height (m) & $1.59 \pm 0.04$ & $1.58 \pm 0.04$ & 0.96 \\
BMI (kg/m²) & $35.3 \pm 2.4$ & $35.4 \pm 2.6$ & 0.88 \\
Fat mass (kg) & $38.2 \pm 3.7$ & $36.9 \pm 5.2$ & 0.51 \\
Fat mass (\%) & $43.1 \pm 2.9$ & $41.4 \pm 3.8$ & 0.25 \\
Abdominal subcutaneous area (cm²) & $479.3 \pm 78.8$ & $470.7 \pm 101.2$ & 0.82 \\
Abdominal visceral area (cm²) & $145.8 \pm 49.9$ & $147.7 \pm 48.8$ & 0.92 \\
VA/SA Ratio & $0.32 \pm 0.14$ & $0.33 \pm 0.13$ & 0.82 \\
\hline (mean \pm SD) & & &
\end{tabular}

(mean \pm SD)

\begin{tabular}{lccc}
\hline Table 3. Metabolic profile according to genotype & & \\
\hline & $\begin{array}{c}\text { N363/363S } \\
\text { (genotype AG) }\end{array}$ & $\begin{array}{c}\text { N363/N363 } \\
\text { (genotype AA) }\end{array}$ & P \\
\hline Subjects & 8 & 48 & \\
Glucose (mg/dL) & $88.0 \pm 10.4$ & $87.0 \pm 8.3$ & 0.52 \\
HOMA-IR score & $8.0 \pm 3.2$ & $6.6 \pm 2.1$ & 0.07 \\
Total cholesterol (mg/dL) & $174.8 \pm 35.2$ & $171.9 \pm 23.0$ & 0.82 \\
HDL-cholesterol (mg/dL) & $47.2 \pm 13.6$ & $42.0 \pm 5.3$ & 0.08 \\
LDL-cholesterol (mg/dL) & $104.5 \pm 32.7$ & $103.2 \pm 21.8$ & 0.92 \\
Triglycerides (mg/dL) & $115.5 \pm 48.5$ & $133.8 \pm 65.7$ & 0.36 \\
APO B (mg/dL) & $98.3 \pm 20.2$ & $90.4 \pm 22.5$ & 0.36 \\
PAl-1 (mg/mL) & $51.5 \pm 6.7$ & $51.7 \pm 7.4$ & 0.94 \\
SBP (mmHg) & $125.0 \pm 10.7$ & $117.0 \pm 11.8$ & 0.08 \\
DBP (mmHg) & $84.4 \pm 11.2$ & $79.5 \pm 7.8$ & 0.14 \\
\hline
\end{tabular}

$\mathrm{SI}$ conversion factors: to convert serum glucose to mmo/L, multiply by 0.0555 ; total, $\mathrm{HDL}$, and LDL cholesterol to $\mathrm{mmo} / \mathrm{L}$, multiply by 0.0259 ; triglycerides to $\mathrm{mmo} / \mathrm{L}$, multiply by 0.0113 . 


\section{DISCUSSION}

In this population the $\mathrm{A} / \mathrm{G}$ genotype frequency was $3.4 \%$ : one of the lowest described for this type of polymorphism when compared to other distinct populations. The prevalence of this type of polymorphism has ranged between $3.9 \%$ and $9.3 \%$ for Caucasian populations of European origin (8-14), and has reached 19.8\% for Australian individuals in Sidney (18). On the other hand, a recent description has reported extremely low frequency for this polymorphism in South Asian individuals living in England (19). Therefore, it seems there is some variation in polymorphism prevalence based on ethnic background. This study did not include Asian ancestry individuals, which could contribute to low polymorphism prevalence in our environment. However, high miscegenation in our country (Brazil) makes the analysis of ethnic influence on individuals' genotypes more difficult to be carried out.

GR's N363S SNP has been associated with obesity, but few studies have assessed the association with body adiposity distribution. In 2001, Dobson and cols. (14) reported increased waist-hip ratio between polymorphism carriers and non-carriers. A CT scan is the golden standard to determine visceral adiposity levels. This is the only study in literature to have assessed the association between N363S SNP and visceral adiposity through abdominal CT scan. Study results have shown no differences in abdominal visceral adiposity levels between polymorphism carriers as compared to paired non-carriers. The fact that no association was found may be an indication that the G-allele has little influence on visceral adiposity deposits in the Brazilian population at least at baseline. Perhaps some interventions - such as use of glucocorticoids at pharmacological dosing, or exposure to fat rich diets - may show differences in visceral adiposity levels in N363S SNP carriers.

Other studies have shown that excess of cortisol is associated with insulin resistance $(20,21)$. There are different techniques to assess insulin sensitivity $(22,23)$. This study assessed insulin resistance through HOMA-IR, which has reported positive correlation with hyperinsulinemic euglycemic clamp (24). The present study has shown a tendency of higher insulin resistance through HOMA in N363S SNP carriers.

Hypercortisolism patients presenting different changes in the metabolism of lipoproteins, including increased plasma triglyceride levels, reduced HDL-cholesterol levels, and increased APO B levels (25) have been reported. This study has detected a tendency towards lower HDL-cholesterol levels in N363S SNP carriers. In 1999, Fraser and cols. (26) investigated the association between cortisol and cardiovascular risk factors in a Scottish population and found a significant inverse relationship between cortisol and HDL-cholesterol. The author suggested cortisol may affect peripheral cholesterol metabolism due to changes in HDL-cholesterol formation. The $363 \mathrm{~S}$ allele may lead to lower HDLcholesterol levels through that mechanism.

It has been described that adipocytes secrete PAI-1 (27). The present study has found that obese patients presented quite high PAI-1 levels, but no differences were found when comparing polymorphism carriers and non-carriers. PAI-l secretion is known to be higher at omental adiposity deposits - even after a dexamethasone stimulus (28). No difference in visceral adiposity levels between N363S SNP carriers and non-carriers was detected by the present study. Therefore, this may have contributed to the fact that no differences in PAI-1 serum levels were found between the groups.

Glucocorticoid in excess may lead to systemic hypertension and cardiovascular adverse effects (29). This study has shown a tendency for SBP higher levels in N363S SNP carriers. The mechanisms through which glucocorticoids cause hypertension are not yet fully understood. Cortisol may directly increase vascular resistance and intravascular volume, thus increasing blood pressure (30). However, such salt and water retention mechanism as a result of glucocorticoid action seems to be induced by cortisol binding to type 1 mineralocorticoid renal receptors. The other glucocorticoid-induced blood pressure increase mechanism is indirect, resulting from insulin resistance. It is known that insulin resistance sponsors hypertension, especially as a result of sympathetic nervous activity, thus causing higher vascular resistance and higher water retention, thus contributing to blood pressure increase (31). Study data - showing a tendency to higher blood pressure levels in addition to higher insulin resistance in N363S SNP carriers - suggest both phenomena may be associated in the study population.

Therefore, N363S SNP carriers in this population showed proneness to unfavorable metabolic changes, such as increased insulin resistance, increased blood pressure levels, and decreased HDL-cholesterol levels, irrespective of visceral adiposity increase.

To conclude, the impact of this polymorphism is small in the study population as prevalence is only $3.4 \%$, although its presence may contribute to the worsening of an individual's metabolic profile. 
Acknowledgments: This work was supported by Fundação de Amparo à Pesquisa do Estado de São Paulo (Fapesp), grant $\mathrm{n}^{\mathrm{o}}$ 00/08793-0.

Disclosure: No potential conflict of interest relevant to this article was reported.

\section{REFERENCES}

1. Ljung T, Andersson B, Bengtsson BA, Bjorntorp P, Marin P. Inhibition of cortisol secretion by dexamethasone in relation to body fat distribution: a dose-response study. Obes Res. 1996;4(3):277-82.

2. Bjorntorp $P$, Rosmond R. Obesity and cortisol. Nutrition. 2000;16:924-36.

3. Faria $C D$, Longui $C A$. Molecular aspects of glucocorticoid sensitivity. Arq Bras Endocrinol Metabol. 2006;50(6):983-95.

4. Evans RM. The steroid and thyroid hormone receptor superfamily. Science. 1988;240:889-95.

5. Leung DY, Bloom JW. Update on glucocorticoid action and resistance. J Allergy Clin Immunol. 2003;111:3-22.

6. Koper JW, Stolk RP, de Lange P, Huizenga NA, Molijn GJ, Pols HA, et al. Lack of association between five polymorphisms in the human glucocorticoid receptor gene and glucocorticoid resistance. Hum Genet. 1997;99:663-8.

7. Jewell CM, Cidlowski JA. Molecular evidence for a link between the N363S glucocorticoid receptor polymorphism and altered gene expression. J Clin Endocrinol Metab. 2007;92(8):3268-77.

8. Huizenga NA, Koper JW, De Lange P, Pols HA, Stolk RP, Burger H, et al. A polymorphism in the glucocorticoid receptor gene may be associated with and increased sensitivity to glucocorticoids in vivo. J Clin Endocrinol Metab. 1998;83:144-51.

9. Lin RC, Wang WY, Morris BJ. High penetrance, overweight, and glucocorticoid receptor variant: case-control study. BMJ. 1999;319:1337-8.

10. Di Blasio AM, van Rossum EF, Maestrini S, Maestrini S, Berselli $M E$, Tagliaferri M, et al. The relation between two polymorphisms in the glucocorticoid receptor gene and body mass index, blood pressure and cholesterol in obese patients. Clin Endocrinol. 2003;59:68-74.

11. Roussel R, Reis AF, Dubois-Laforgue D, Bellanne-Chantelot C, Timsit J, Velho G. The N363S polymorphism in the glucocorticoid receptor gene is associated with overweight in subjects with type 2 diabetes mellitus. Clin Endocrinol. 2003;59:237-41.

12. Echwald SM, Sorensen TI, Andersen T, Pedersen O. The Asn363Ser variant of the glucocorticoid receptor gene is not associated with obesity or weight gain in Danish men. Int J Obes Relat Metab Disord. 2001;25:1563-5.

13. Rosmond R, Bouchard C, Bjorntorp P. Tsp509l polymorphism in exon 2 of the glucocorticoid receptor gene in relation to obesity and cortisol secretion: cohort study. BMJ. 2001;322:652-3.

14. Dobson MG, Redfern CP, Unwin N, Weaver JU. The N363S polymorphism of the glucocorticoid receptor: potential contribution to central obesity in men and lack of association with other risk factors for coronary heart disease and diabetes mellitus. J Clin Endocrinol Metab. 2001;86:2270-4.
15. Wajchenberg BL. Subcutaneous and visceral adipose tissue: their relation to the metabolic syndrome. Endocr Rev. 2000;21:697-738.

16. Sjöström ML, Kvist H. Regional body fat measurements with $C T$ scan and evaluation of anthropometric predictions. Acta Med Scand. 1988;723:169-77.

17. Matthews DR, Hosker JP, Rudenski AS, Naylor BA, Treacher DF, Turner RC. Homeostasis model assessment: insulin resistance and beta-cell function from fasting plasma glucose and insulin concentrations in man. Diabetologia. 1985;28:412-9.

18. Lin RC, Wang $X L$, Morris BJ. Association of coronary artery disease with glucocorticoid receptor N363S variant. Hypertension. 2003;41:404-7.

19. Syed AA, Irving JA, Redfern CP, Hall AG, Unwin NC, White M, et al. Low prevalence of the N363S polymorphism of the glucocorticoid receptor in South Asians living in the United Kingdom. J Clin Endocrinol Metab. 2004;89:232-5.

20. Chavez M, Seeley RJ, Green PK, Wilkinson CW, Schwartz MW, Woods SC. Adrenalectomy increases sensitivity to central insulin. Physiol Behav. 1997;62:631-4.

21. Andrews RC, Walker BR. Glucocorticoids and insulin resistance: old hormones, new targets. Clin Sci. 1999;96:513-23.

22. Ferrannini $E$, Mari A. How to measure insulin sensitivity. J Hypertens. 1998;16:895-906.

23. Geloneze B, Tambascia MA. Laboratorial evaluation and diagnosis of insulin resistance. Arq Bras Endocrinol Metabol. 2006;50:208-15.

24. Bonora E, Targher G, Alberiche M, Bonadonna RC, Saggiani $F$, Zenere $\mathrm{MB}$, et al. Homeostasis model assessment closely mirrors the glucose clamp technique in the assessment of insulin sensitivity: studies in subjects with various degrees of glucose tolerance and insulin sensitivity. Diabetes Care. 2000;23:57-63.

25. Friedman TC, Mastorakos G, Newman TD, Mullen NM, Horton EG, Costello R, et al. Carbohydrate and lipid metabolism in endogenous hypercortisolism: shared features with metabolic syndrome $X$ and NIDDM. Endocr J. 1996;43:645-55.

26. Fraser R, Ingram MC, Anderson NH, Morrison C, Davies E, Connell JM. Cortisol effects on body mass, blood pressure, and cholesterol in the general population. Hypertension. 1999;33:1364-8.

27. Shimomura I, Funahashi T, Takahashi M, Maeda K, Kotani K, Nakamura T, et al. Enhanced expression of PAl-1 in visceral fat: possible contributor to vascular disease in obesity. Nat Med. 1996;2:800-3.

28. Halleux CM, Declerck PJ, Tran SL, Detry R, Brichard SM. Hormonal control of plasminogen activator inhibitor-1 gene expression and production in human adipose tissue: stimulation by glucocorticoids and inhibition by catecholamines. J Clin Endocrinol Metab. 1999;84:4097-105.

29. Whitworth JA, Mangos GJ, Kelly JJ. Cushing, cortisol, and cardiovascular disease. Hypertension. 2000;36:912-6.

30. Whitworth JA, Gordon D, Andrews J, Scoggins BA. The hypertensive effect of synthetic glucocorticoids in man: role of sodium and volume. J Hypertens. 1989;7:537-49.

31. Scherrer U, Sartori C. Insulin as a vascular and sympathoexcitatory hormone: implications for blood pressure regulation, insulin sensitivity, and cardiovascular morbidity. Circulation. 1997:96:4104-13. 